\title{
Petrographical analysis of Warthian fluvioglacial gravels as a tool to trace the source area - a case study from central Poland
}

\author{
Maria Górska-Zabielska1, ${ }^{1,}$, Lucyna Wachecka-Kotkowska² \\ ${ }^{1}$ Institute of Geoecology and Geoinformation, Adam Mickiewicz University, Dziegielowa 27, 61-680 Poznań, Poland; \\ e-mail: gorska@man.poznan.pl \\ ${ }^{2}$ Department of Geomorphology and Palaeogeography, Faculty of Geographical Sciences, University of Łódź, \\ Narutowicza 88, 90-139 Łódź, Poland; e-mail: kotkow@geo.uni.lodz.pl \\ * corresponding author
}

\begin{abstract}
The petrographical features of the medium- and coarse-grained gravels (4-10 mm and 20-60 $\mathrm{mm}$, respectively) of weathered and fresh (unweathered) deposits indicate, in combination with so-called indicator and statistical erratics, that two glacial lobes joined in the borderland of the Polish Lowlands and Uplands. Lower Palaeozoic limestones become less frequent in the finer gravel fraction, whereas crystalline rocks and flints become more frequent. The petrographical analysis of the coarser gravel fraction indicates that the ice sheet advanced from the NE to NNW (the Widawka lobe) and from the NE to ENE (the Rawka, Pilica and Luciąża lobes). The source areas of the gravel deposited by the Warthian ice sheet were magmatic and sedimentary areas of both the Baltic and the SE Sweden basins.
\end{abstract}

Keywords: gravel petrography, indicator erratics, fluvioglacial deposits, Warthian stadial, central Poland

\section{Introduction}

Quantitative analysis of the petrography of gravel fractions indicates how and in how far particular petrographical groups in glacial and fluvioglacial sediments change, in time and/or space. Such analyses have resulted in numerous often significantly different -lithostratigraphic schemes (e.g. Lüttig, 1958, 1995, 1999; Cepek, 1962, 1973, 1975, 1981; Rühberg \& Krienke, 1977; Böse, 1979, 1983, 1989, 1995; Meyer, 1994, 1998, 2000; Czerwonka \& Krzyszkowski, 1994; Lisicki, 1998 a,b; Zabielski, 1996; Rühberg, 1999; Krienke, 2003). The results of petrographical analyses are usually aimed at helping to establish a lithostratigraphic correlation of deposits in a comparable stratigraphic succession (e.g. Czerwonka \& Krzyszkowski, 1994), but in specific cases they may also be used for regional lithostratigraphic correlation.
Petrographical analysis in combination with identification of Scandinavian erratics tends to give an indication of the Scandinavian source areas and to suggest ice-sheet transgression route or individual zones of ice movement during its advance. This is obvious, for instance, the Warthian stadial of the Odranian glaciation in the border area between the lowlands and uplands of central Poland (Figs 1, 2).

The significance of petrographical analyses, of both medium- and coarse-gravel fractions, is therefore huge: they complement lithofacies analysis as applied by Kasprzak \& Kozarski (1984) regarding Quaternary deposits. They confirm the hypothesis about the lithostratigraphy as determined earlier (e.g. Kozarski, 1988; Kasprzak, 1985, 1992, 1997; Böse, 1989, 1995; Böse \& Górska, 1995; Pettersson, 1995, 1997, 2002 ).

The petrographical investigation of medium-sized gravel of glacial tills became a standard 


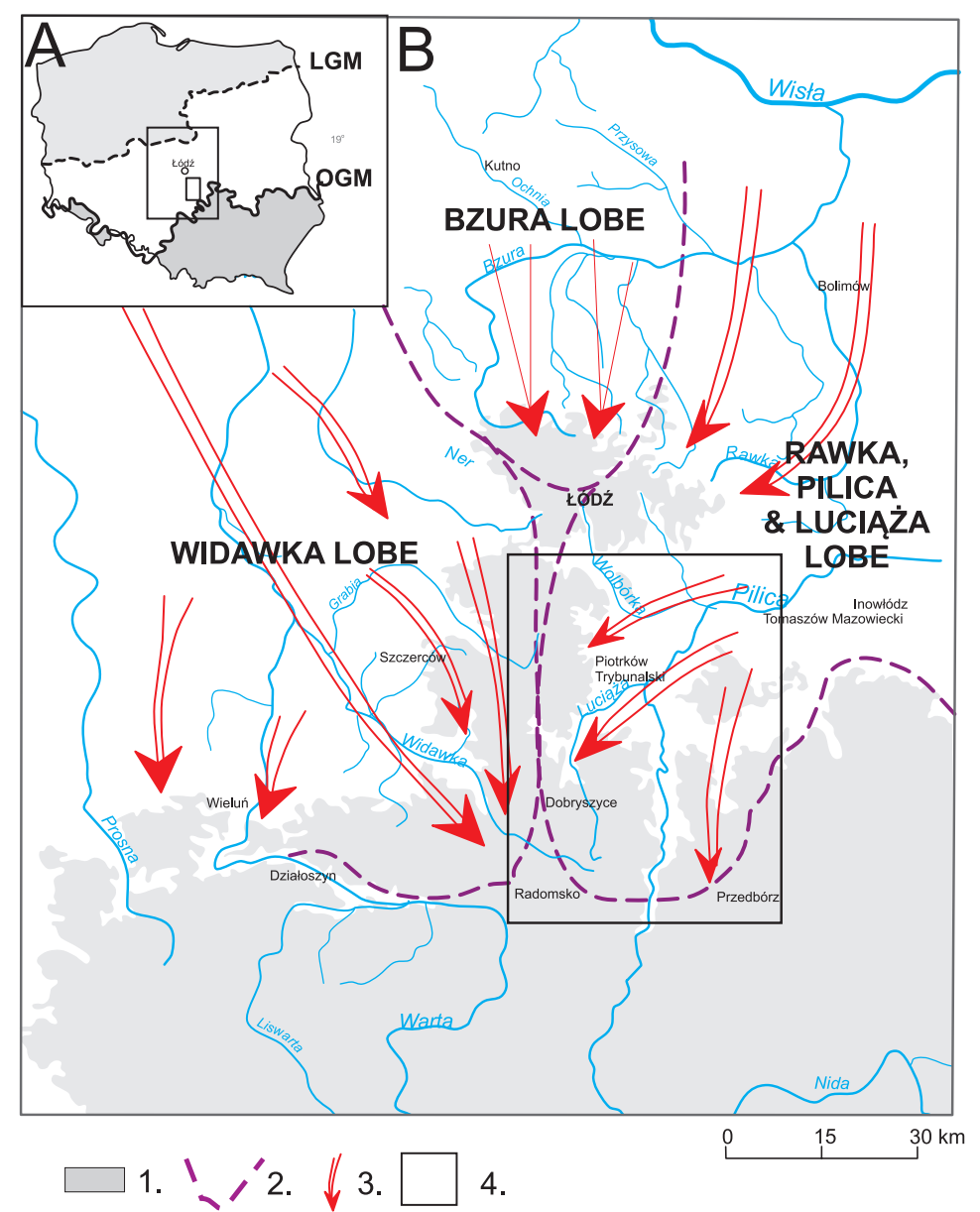

Fig. 1. Lobes of the ice-marginal zone during the Warthian stadial in central Poland. Slightly modified after Turkowska (2006) A: Location of the study area in central Poland. OGM = Odra Glacial Maximum; LGM = Last Glacial Maximum; B: 1 = area over $200 \mathrm{~m}$ above sea level; 2 = ice-sheet extent; $3=$ directions of the ice-sheet advance; $4=$ study area

type of investigation when the Detailed Geological Map of Poland (DGMP) at scale 1:50 000 was prepared. This led to much more common use of this type of research. Yet, petrographical examination of gravel from fluvioglacial deposits is still, regardless of the size fraction, carried out rarely: a missed chance.

The main cause of the relatively small attention for the gravel in fluvioglacial deposits is, apart from the problem of painstaking, time-consuming analyses, the large influence of post-depositional processes on the final petrographical composition of these deposits.

It is remarkable in this context that fluvioglacial deposits are in Poland considered hardly useful for petrographical analyses, whereas German investigators publish results of analyses of Scandinavian indicator erratics for many types of glacigenic deposits; they started doing so already in the beginning of the 1990s (e.g. Lüttig, 1991, 1997b, 1999, 2005). Lüttig based his stratigraphic interpretation even on such research of fluvioglacial and periglacial deposits and even on the gravels from river terraces. Petrographical analyses of medium to coarse gravel from fluvial, limnic and other proglacial were also carried out by, among others, Badura et al. (1992), Czerwonka et al. (1997) and Meyer (2000). It should be clearly stressed, however, that the objective was first of all a lithostratigraphical division of the Pleistocene deposits.

Successful petrographical analyses of fluvioglacial deposits had been conducted also elsewhere, for instance in Lithuania and Latvia (Jurgaitis, 1969, 1984; Danilans, 1973; Mikalajskas, 1985). The usefulness of petrographical analysis of fluvioglacial gravel has not been truly neglected by Saarnisto (1990) either.

Earlier research of glacial tills and the accompanying simultaneous fluvioglacial deposits at Koczery in the area of Podlasie at Wardyń in Pojezierze Drawskie (the Drawskie Lakeland) (Górska, 2002b), and at Sobolewo in Suwalszczyzna (the Suwałki region) (Górska, 2006b) indicate that only small differences exist in the percentages of the various petrographical groups of the medium coarse gravel between glacial tills and fluvioglacial deposits. Analyses of indicator erratics of the coarse-gravel fraction deposited during the same advance of the Scandinavian ice sheet, also showed largely similar results. 
Fig. 2. Location of the sites in the four zones (I-IV) and extent of the icesheet lobes during the Warthian stadial

TSC from till $=$ Theoretical Stone Centre calculated from glacial till; TSC from flgl = Theoretical Stone Centre calculated from fluvioglacial sediments, 4-10 petr. an. flgl $=$ petrographical analysis conducted on 4-10 $\mathrm{mm}$ gravel derived from fluvioglacial sediments

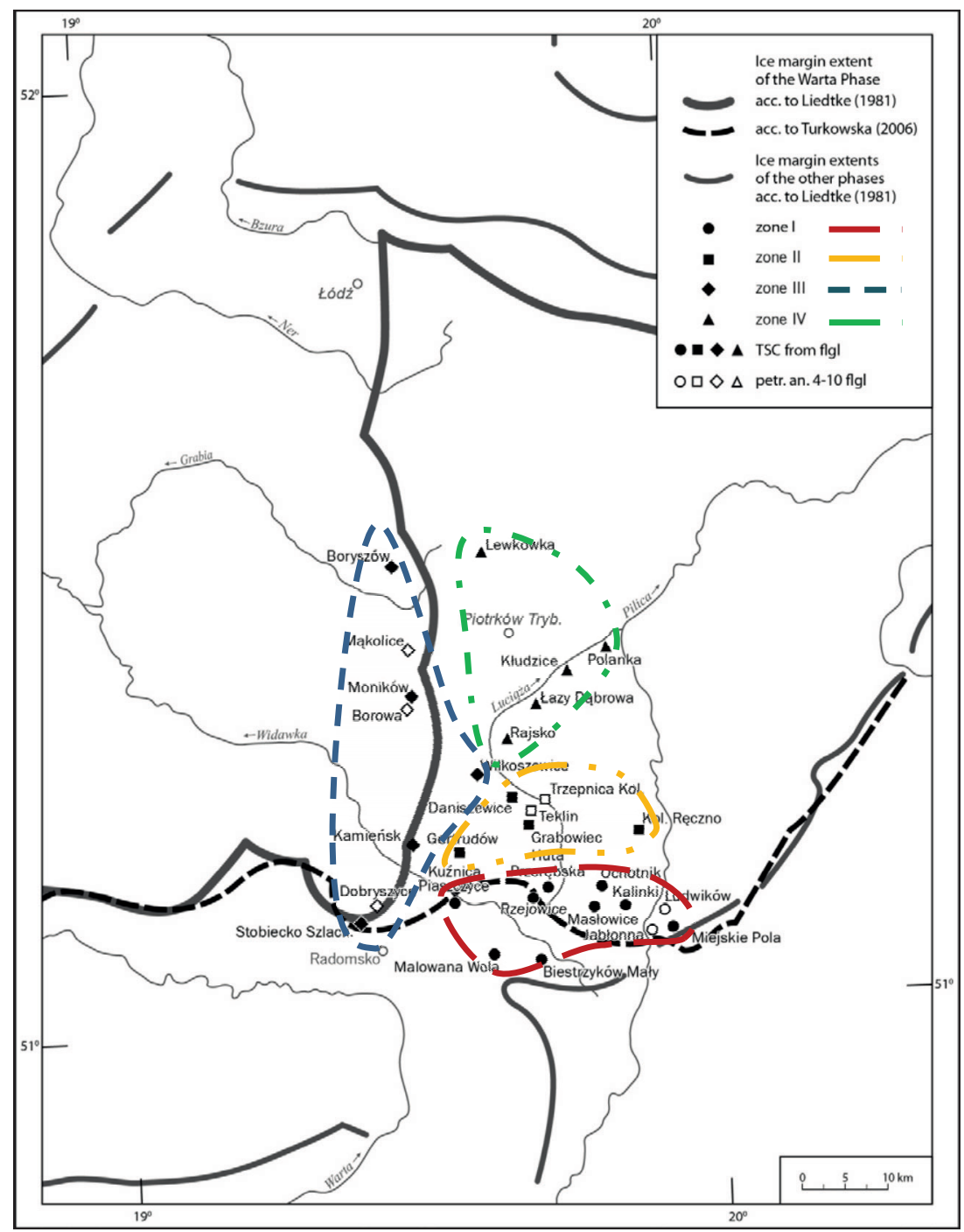

More recently, Lipka (2011) has presented a detailed study of the spatial petrological differences of glacial deposits in the Wysoczyzna Lubuska area (Lubuska Upland). She proved that no statistically substantial differences exist between the components of the glacial deposits and the related fluvioglacial deposits. This implies the possibility of comparing the petrographical compositions of glacial tills and fluvioglacial deposits. This conclusion is of utmost importance if a statistically significant analysis must be carried out while it is difficult to take sufficiently large samples for petrographical analysis, with sufficient numbers of clasts, as shown by the studies of Czubla \& Wachecka-Kotkowska (2009) and Wachecka-Kotkowska et al. $(2012,2013)$.

\section{Objectives}

The present study was carried out in order to get a better insight into the petrographical composition of the medium- and coarse-grained gravels which form part of the fluvioglacial deposits in the area between Radomsko, Przedbórz and Piotrków Trybunalski (Fig. 2). For the first time, this study of the coarse gravel (20-60 $\mathrm{mm}$ ) of the fluvioglacial deposits of this area includes a detailed analysis of indicator and statistical erratics. It is supplemented with the identification of the petrographical components of the medium-sized gravel $(4-10 \mathrm{~mm})$ of the same deposits.

The petrographical analysis was combined with structural and texture analyses of the glacial deposits, because these are important for a good understanding of the morphogenesis of the study area.

It was hypothesised that the fluvioglacial deposits within the marginal landforms related to the Rawka, Pilica and Luciąża Lobe (zone I and II), the Widawka Lobe (zone III) and the Piotrków till plain (zone IV), had different petrographical features (see Figs 1 and 2). The main purpose of the analyses described here is to accept or reject this hypothesis. 
The results of the petrographical investigation are expected to help reconstructing the direction(s) of the ice-sheet advance (Fig. 1), taking into account the bedrock configuration.

\section{Methods}

\subsection{Sampling}

The method of sampling medium-sized (4-10 $\mathrm{mm})$ and coarse-sized gravel $(20-60 \mathrm{~mm})$ fractions follows that of other authors (e.g. Górska, 2000, 2006; Górska-Zabielska, 2008; Górska-Zabielska \& Zabielski, 2010, 2011). Only the main procedures will therefore be described below.

Samples were collected at 29 sites in both active and abandoned gravel and sand pits. The locations and the number and type of the samples are presented in Table 1.

Indicator erratics were investigated following Lüttig (1958); other particles derived from recognizable rock units (so-called 'statistical rocks') were investigated according to Smed (1993); these to gravel categories were selected from seven samples of coarse-grained gravel. Each time a statistically representative sample was subjected to analysis.

The principles of statistics (Stanisz, 2001) imply that correct conclusions can be obtained on the basis of a sample consisting of only thirty elements. Taking into consideration the existing experience with petrographical analysis of indicator erratics, however, the population of the sample was arranged in compliance with the methodical recommendation by Smed (1993) who states that correct conclusions can be drawn only after analysis of fifty definite indicator erratics in the $20-60 \mathrm{~mm}$ fraction. Taking into account that barely $10 \%$ of the investigated er-

Table 1. Zones (I-IV) of the study area with sampling sites and number of samples of the medium (4-10 mm) and coarse (20-60 mm) fractions from the fluvioglacial gravel

\begin{tabular}{|c|c|c|c|}
\hline Zones & Sites & $\begin{array}{l}\text { 4-10 mm } \\
\text { (between brackets: number } \\
\text { of samples of fresh gravel) }\end{array}$ & $\begin{array}{c}20-60 \mathrm{~mm} \\
\text { (between brackets: num- } \\
\text { ber of samples of fresh } \\
\text { gravel) }\end{array}$ \\
\hline $\begin{array}{l}\text { I } \\
\text { Radomsko Hills and Przed- } \\
\text { bórz Upland }\end{array}$ & $\begin{array}{l}\text { Jabłonna } \\
\text { Ludwików } \\
\text { Miejskie Pole } \\
\text { Masłowice } \\
\text { Kuźnica } \\
\text { Ochotnik } \\
\text { Kalinki } \\
\text { Biestrzyków Mały } \\
\text { Malowana Wola } \\
\text { Rzejowice } \\
\text { Wola Przerębska }\end{array}$ & $\begin{array}{l}1(1) \\
2(2) \\
2(2) \\
2(1) \\
2(0) \\
2(2) \\
1(1) \\
1(0) \\
1(0) \\
1(0) \\
1(1)\end{array}$ & $\begin{array}{l}1(1) \\
1(1)\end{array}$ \\
\hline $\begin{array}{l}\text { II } \\
\text { Dobryszyce Hills, } \\
\text { centre of the study area }\end{array}$ & $\begin{array}{l}\text { Kol. Ręczno } \\
\text { Teklin } \\
\text { Grabowiec } \\
\text { Trzepnica Kolonia } \\
\text { Daniszewice } \\
\text { Gertrudów }\end{array}$ & $\begin{array}{l}1(1) \\
5(5) \\
1(0) \\
4(0) \\
3(3) \\
1(0)\end{array}$ & $\begin{array}{c}1(1) \\
1\end{array}$ \\
\hline $\begin{array}{l}\text { III } \\
\text { Bełchatów Plateau, } \\
\text { Widawka Lobe } \\
\text { of the Wartanian ice sheet }\end{array}$ & $\begin{array}{l}\text { Borowa } \\
\text { Dobryszyce } \\
\text { Mąkolice } \\
\text { Stobiecko } \\
\text { Boryszów } \\
\text { Wilkoszewice } \\
\text { Kamieńsk } \\
\text { Moników }\end{array}$ & $\begin{array}{l}2(1) \\
3(1) \\
6(3) \\
3(2) \\
1(0) \\
2(2) \\
3(1) \\
1(1)\end{array}$ & $\begin{array}{l}1(1) \\
1(1) \\
1\end{array}$ \\
\hline $\begin{array}{l}\text { IV } \\
\text { Piotrków Plain }\end{array}$ & $\begin{array}{l}\text { Kłudzice } \\
\text { Lewkówka } \\
\text { Polanka } \\
\text { Rajsko Małe }\end{array}$ & $\begin{array}{l}1(0) \\
6(2) \\
2(0) \\
1(0)\end{array}$ & \\
\hline Total & & $62(32)$ & $7(5)$ \\
\hline
\end{tabular}


ratics meet the requirements of an indicator erratic (Meyer, 1983), it was tried to ensure each sample was large enough. Such a sample should contain at least five hundred specimens, including sandstones, flints and carbonate rocks. When sampling the erratics of the coarse-gravel fraction, the present authors followed also their own experiences (Böse \& Górska, 1995; Górska, 2000, 2002a, b, 2006).

With regard to both the advantages and disadvantages of petrographical analyses (Górska, 1999), the samples for analysis were supplemented by medium gravel (4-10 mm). This was done because, due to the frequent lack of coarse gravel, only medium-gravel fraction could sometimes be used for petrographical analysis.

The samples of glacial deposits were taken from long profiles prepared in a cleaned wall of the outcrop, below the soil horizon. The laboratory analyses show, however, that a weathered horizon must have been sampled at some places as well. The volume of samples for petrographical analysis of medium- and coarse-gravel fractions was set in accordance with the methodological recommendations of Trembaczowski (1961) and Rutkowski (1995a, b), depending on the percentage of these fractions in the deposit.

For the petrographical analyses of the Fennoscandian erratics, a first segregation of the coarsegrained gravel was carried out out in the field. All erratics of the 20-60 mm fraction were broken in order to study the fresh surface. The clasts were then provisionally identified, and the carbonate (Palaeozoic and the Mesozoic limestones and dolomites) and flint clasts were separated from the rest. This group constituted about half of the original sample, which consisted of petrographically strongly varied groups of effusive and hypogenic magmatic rocks as well as of other sedimentary rocks. These required further petrographical analysis in the laboratory.

\subsection{Laboratory analyses}

Laboratory analyses included segregation on the basis of their petrology of erratic material of the 4-10 $\mathrm{mm}$ and the $20-60 \mathrm{~mm}$ fractions. The analysis of the former fraction was made for clasts from both unweathered deposits and deposits showing post-depositional changes.

\subsubsection{Petrographical analysis of the $4-10 \mathrm{~mm}$ fraction}

The petrographical composition of 62 samples of medium-sized gravel was analysed for the 4-10 $\mathrm{mm}$ fraction; 32 samples came from unweathered deposits and 30 from weathered deposits (Table 1). This fraction is commonly investigated in Poland (e.g. Górska, 2000, 2002a, b; Lipka, 2011), which makes it possible to compare the outcome with previously obtained data. The analysis was carried out following Trembaczowski (1961) and Rutkowski (1995a).

Cepek (1969) and Böse (1989) suggest to exclude samples from weathered deposits, as their results may affect the original petrographical composition, but they restricted their investigations to glacial tills in areas where almost all gravel contain carbonates. In central Poland, however, where the present study was carried out, the fluvioglacial deposits contain fresh, weathered and even over-weathered gravel clasts.

Ten petrographical groups were from the samples of at least 300 clasts (Table 2). The identification of the clasts followed commonly used criteria (see Table 2.4 in Górska, 2000) using a geological magnifying glass, $10 \% \mathrm{HCl}$ and a Magneson I indicator (Cepek, 1969). Samples from glacial deposits with a too numerous population of petrographical components were investigated applying the method of quartering (Rutkowski, 1995b).

The outcomes of the petrographical analyses are presented separately for the unweathered and the weathered deposits in order to prevent an incorrect impression because some petrographical components may, if weathered, have fallen in many fragments, thus seemingly being over-represented.

The petrographical analyses were carried out separately for each zone (I-IV) (Fig. 2). Cumulated histograms (Figs 4-11) compile the data from the various sites from the most northern sites in a given zone (upper part of the graph) to the southernmost sites (lower part of graph). The proportion of individual petrographical groups, as presented in figures and tables, is given as a percentage.

Table 2. Petrographical types of rock distinguished in the present study and their symbols

\begin{tabular}{|cl|}
\hline Symbol & \multicolumn{1}{c|}{ Petrographical type of rock } \\
\hline Cr & crystallines \\
\hline LP1 & grey Lower Palaeozoic limestones \\
LP12 & red Lower Palaeozoic limestones \\
Cl & Cretaceous limestones \\
D & dolomites \\
S & sandstones \\
Ps & Palaeozoic slates \\
F & flint \\
Q & quartz \\
mQ & milk quartz \\
\hline
\end{tabular}




\subsubsection{Analysis of the indicator erratics}

The petrographical analysis of the 20-60 mm clasts was carried out for seven samples from fluvioglacial deposits (Table 1). The erratics are subdivided into ten petrographical groups (Table 2) and the Fennoscandian indicator and statistical erratics were identified (Fig. 3). After a first petrographical segregation of the erratics in the field, the analysis was continued in the laboratory, where the whole range of Fennoscandian rocks was considered. The indicator erratics were identified following Lüttig (1958), Meyer (1983, 1985), Smed (1993), Zandstra (1999) and Smed \& Ehlers (2002). Atlases of Scandinavian indicator erratics (Korn, 1927; Hesemann, 1975; Smed \& Ehlers, 2002; Zandstra, 1999; Schulz, 2003; Rudolph, 2005; Svenson, 2005) were used for the identification. The collection of comparative rocks housed in the Institute of Geoecology and Geoinformation of Adam Mickiewicz University in Poznań was also used.

Figure 3 shows the location of the outcrops of the most common Scandinavian indicator rocks.
These points are marked with the numbers 1-24. The spatial spreading of the outcrops of the most common indicator sedimentary rocks is shown by different shades, along with symbols marking the centres of the source areas of selected, so-called 'statistical' (Vinx, 1993) erratics (letters A-E).

\section{Results of the petrographical analysis of the 4-10 $\mathbf{~ m m}$ fraction}

\subsection{Zone I: Radomsko Hills}

More than half of the gravels from fresh (unweathered) samples (51.6\%; Fig. 4; Table 3) from the oldest glacigenic deposits in the area were identified as derived from Lower Palaeozoic limestones (LP11). These deposits may in principle be the ones that were affected most by post-depositional processes such as chemical decomposition of carbonates. Hence, they might be expected to be
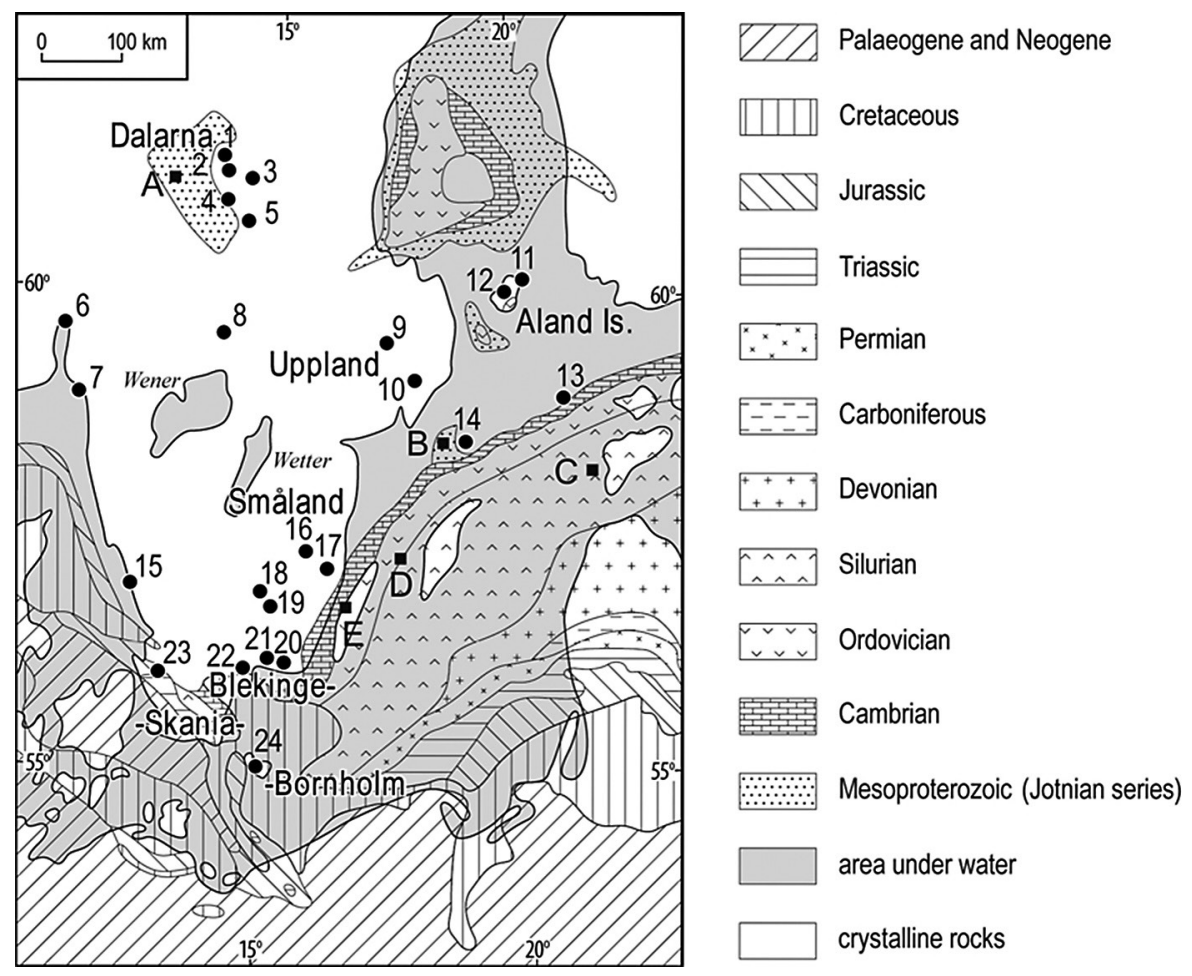

Fig. 3. Location of the source areas of the indicator erratics $(\bullet)$ and of the source areas of the statistical erratics ( Indicator erratics $(\bullet): 1$ = Bredvad porphyry; 2 = Garberg granite; $3=$ Grönklitt porphyrite; $4=$ Dalarna porphyry; 5 = Siljan granite; 6 = Oslo porphyry; 7 = Bohus granite; $8=$ Filipstad granite; $9=$ Uppsala granite; $10=$ Stockholm granite; 11 = Åland granite and Åland rapakivi granite; 12 = Åland quartz porphyry; 13 = red Baltic porphyry; 14 = brown Baltic porphyry; 15 = charnockite; 16 = Småland granite; 17 = Påskallavik porphyry; 18 = grey Växjö granite; 19 = red Växjö granite; 20 = Karlshamn granite; 21 = Halen granite; 22 = Vånga granite; 23 = Scania basalt; 24 = granites and gneisses from Bornholm

Statistical erratics (ם): A = Dalarna sandstone; B = Jotnian sandstone; C = east-Baltic limestone; $\mathrm{D}=$ Palaeoporella limestone; $\mathrm{E}=$ red Ordovician limestone 
Table 3. Average percentages of some types of petrographical groups in fresh gravel from the four zones of the study area. For symbols of the petrographica types, see Table 2

\begin{tabular}{cccccc}
\hline Zone & Cr [\%] & $\begin{array}{c}\text { LPl1 } \\
\text { [\%] }\end{array}$ & S [\%] & F [\%] & Q [\%] \\
\hline I & 37.6 & 51.6 & 7.4 & 0.3 & 1.4 \\
\hline II & 43.0 & 42.9 & 8.4 & 1.0 & 2.4 \\
\hline III & 41.4 & 41.1 & 8.3 & 1.6 & 3.5 \\
\hline IV & 45.8 & 32.9 & 7.3 & 1.4 & 5.9 \\
\hline
\end{tabular}

impoverished in carbonate clasts, but the opposite is true.

In the north-eastern part of the zone (sites: Jabłonna, Miejskie Pola, Ludwików, Kalinki, Masłowice, Ochotnik and Kolonia Przerębska), grey Silurian limestones, accompanied by red Ordovician limestones, form the largest group. The second petrographical group consists of crystalline rocks (37.6\% on average). The third petrographical group consists of sandstones (7.4\%). Flints, which are fairly resistant to weathering, make up only a negligible amount $(0.3 \%)$. Quartz clasts, highly resistance to destruction, reach only $1.4 \%$.

In the western part of zone I (sites: Kuźnica Piaszczyce, Rzejowice, Malowana Woda and Biestrzyków Mały), the 4-10 mm fraction is devoid of grey and red Lower Palaeozoic limestones. The dominant petrographical group in these weathered sediments consists of crystalline rocks $(67.7 \%$; Table 4; Fig. 5); more than three times less frequent is the group of sandstones (18.3\%). Quartz amounts to $8.4 \%$, and flints to $3.4 \%$ of all gravel clasts from the six samples.

\subsection{Zone II: Dobryszyce Hills}

The clasts from unweathered deposits were examined for nine samples from three sites; they have comparable amounts of carbonate rocks (LPl1 $42.9 \%+\mathrm{LPl} 20.8 \%+\mathrm{Cl} 0.4 \%$ ) and crystalline rocks (Cr almost 43\%; Table 3; Fig. 6). None of the petrographical groups dominates. It is worth noting that the grey Silurian limestones are always accompanied by the red Ordovician limestones. The sandstones make up $8.4 \%$ of the gravel. In comparison with zone I, the gravel of zone II has a higher percentage of quartz $(2.4 \%)$ and flint $(1.0 \%)$.

In the group of six samples without carbonate rocks (Table 4, Fig. 7), crystalline rocks dominate (57.5\%); sandstones make up a little more than $20 \%$. Quartz makes up as much as $14.4 \%$. This is remarkable because zones III and IV, as far as
Table 4. Average percentages of some types of petrographical groups in weathered gravel from the four zones of the study area. For symbols of the petrographical types, see Table 2

\begin{tabular}{ccccr}
\hline Zone & Cr [\%] & S [\%] & F [\%] & Q [\%] \\
I & 67.7 & 18.3 & 3.4 & 8.4 \\
II & 57.5 & 20.5 & 5.8 & 14.4 \\
III & 71.9 & 16.8 & 1.9 & 7.5 \\
IV & 76.0 & 12.8 & 1.8 & 6.7 \\
\hline
\end{tabular}

weathered sediments are concerned, contain only about half of this amount of quartz (Table 4). The percentage of flint is also the highest in zone II $(5.8 \%)$.

\subsection{Zone III: Bełchatów Plateau, Widawka River lobe of the Warthian ice sheet}

The eight sites of this zone, from which 21 samples were collected, are located on the Bełchatów Plateau. Eleven samples come from fresh deposits (Fig. 8), end ten from weathered deposits (Fig. 9).

The samples from the fresh deposits show comparable percentages of carbonate rocks (LPI1 41.1\% + $\mathrm{LPl} 21.1 \%+\mathrm{Cl} 1.2 \%$ ) and crystalline rocks $(41.4 \%)$ (Table 3). The red Ordovician limestones always accompany the grey Silurian limestones, apart from at the Moników site. The percentage of sandstones among the gravel clasts is comparable to that in the other zones. The content of flints is higher in zone III $(1.6 \%)$ than in the other zones. The gravel contains $3.5 \%$ of quartz grains; quartz systematically increases from zone I to zone IV.

The percentage of fragile Cretaceous limestones is twice as high $(\mathrm{Cl} 1.2 \%)$ as in the neighbouring zones; they occur at three sites in the central part of zone III: Borowa, Moników and Dobryszyce (Fig. 8); in the other zones they occur only rarely, in amounts not exceeding $0.6 \%$.

The weathered gravels are distinctly dominated by crystalline rocks ( $\mathrm{Cr} 71.9 \%)$, with a secondary role for sandstones (S 16.8\%; Table 4). The percentage of sandstone clasts ranges from 8.0 to $14.7 \%$, except for two samples from Kamieńsk, where they show an exceptional value of some $48 \%$ (Fig. 9): the largest percentage of sandstone of all 62 samples collected from the entire study area.

The high percentage of crystalline rocks in the weathered deposits was expected to be accompanied by a large amount of quartz, as this mineral is resistant to diagenetic weathering, but its value does not exceed $7.5 \%$ (Table 4). This is only half the 

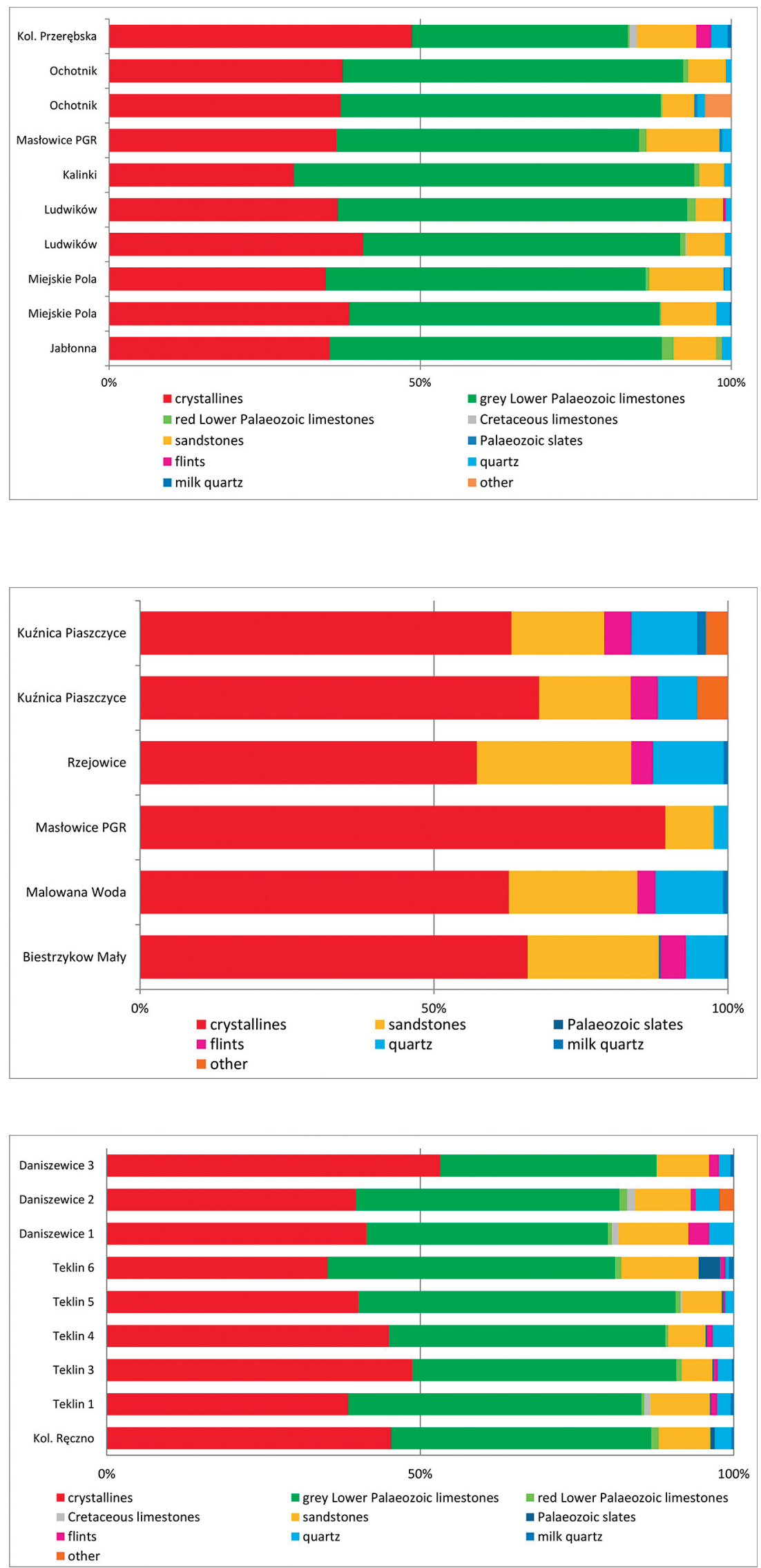

Fig. 4. Percentages of the various petrographical groups of the Warthian fluvioglacial fresh gravel (4-10 mm fraction) in zone I (Radomsko Hills) (for legend see Table 2)

Fig. 5. Percentages of the various petrographical groups of the Warthian fluvioglacial weathered gravel (4-10 $\mathrm{mm}$ fraction) in zone I (Radomsko Hills) (for legend see Table 2).

Fig. 6. Percentages of the various petrographical groups of the Warthian fluvioglacial fresh gravel (4-10 $\mathrm{mm}$ fraction) in zone II (Dobryszyce Hills) (for legend see Table 2) 
Fig. 7. Percentages of the various petrographical groups of the Warthian fluvioglacial weathered gravel (4-10 $\mathrm{mm}$ fraction) in zone II (Dobryszyce Hills and Radomsko Hills) (for legend see Table 2)

Fig. 8. Percentages of the various petrographical groups of the Warthian fluvioglacial fresh gravel (4-10 mm fraction) in zone III (Bełchatów Plateau) (for legend see Table 2)

Fig. 9. Percentages of the various petrographical groups of the Warthian fluvioglacial weathered gravel (4-10 $\mathrm{mm}$ fraction) in zone III (the Bełchatów Plateau) (for legend see Table 2)
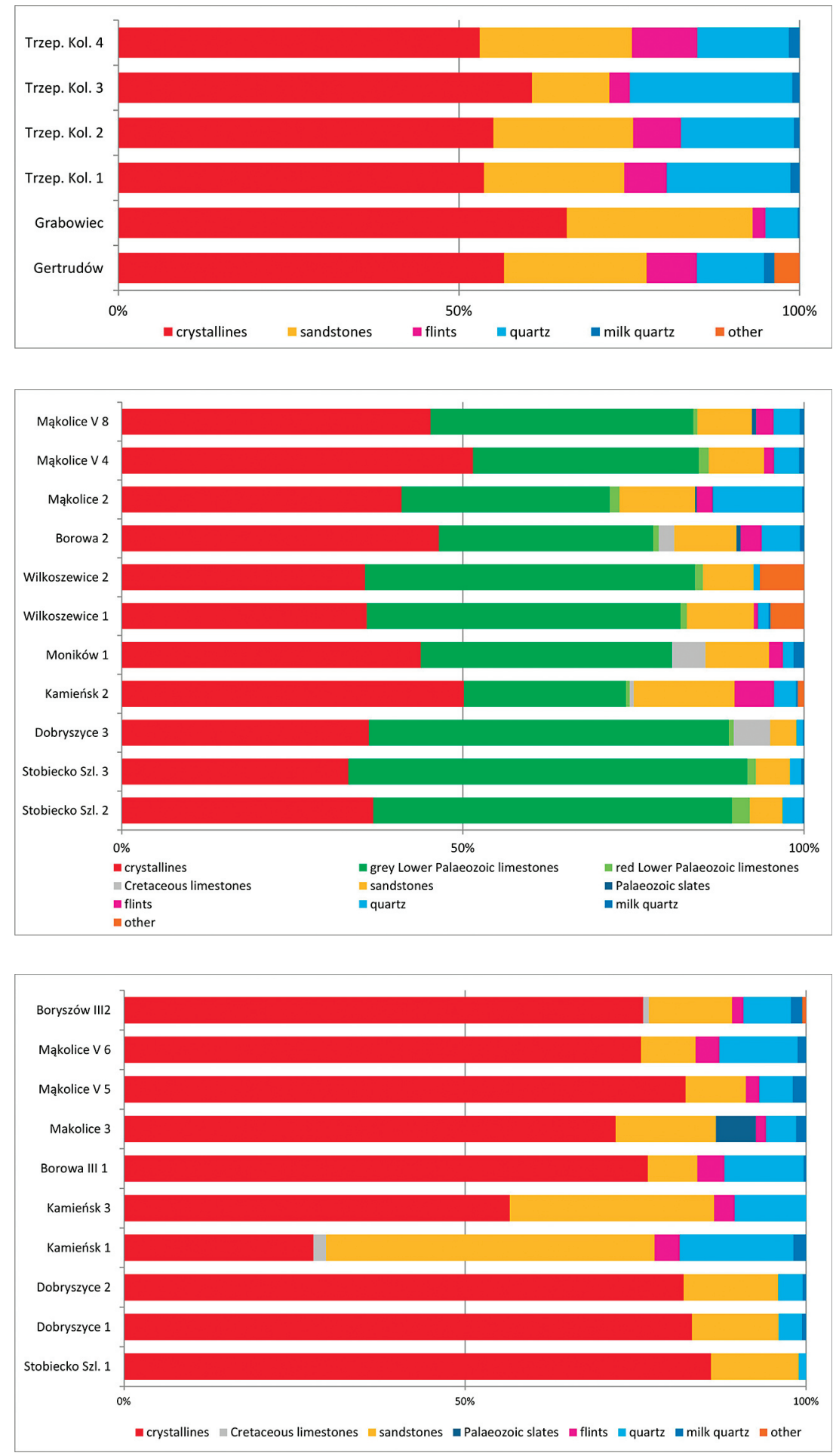

value of quartz in zone II. Flint does not occur in large numbers either $(1.9 \%)$.

The gravels from Mąkolice show much variation. This is because the samples were collected from various parts of an end-morainic hummock.

\subsection{Zone IV: the Piotrków Plain}

The ten samples from zone IV lack carbonate rocks except for two samples from Lewkówka (Fig. $10)$, where the gravel composition is unusual due to 

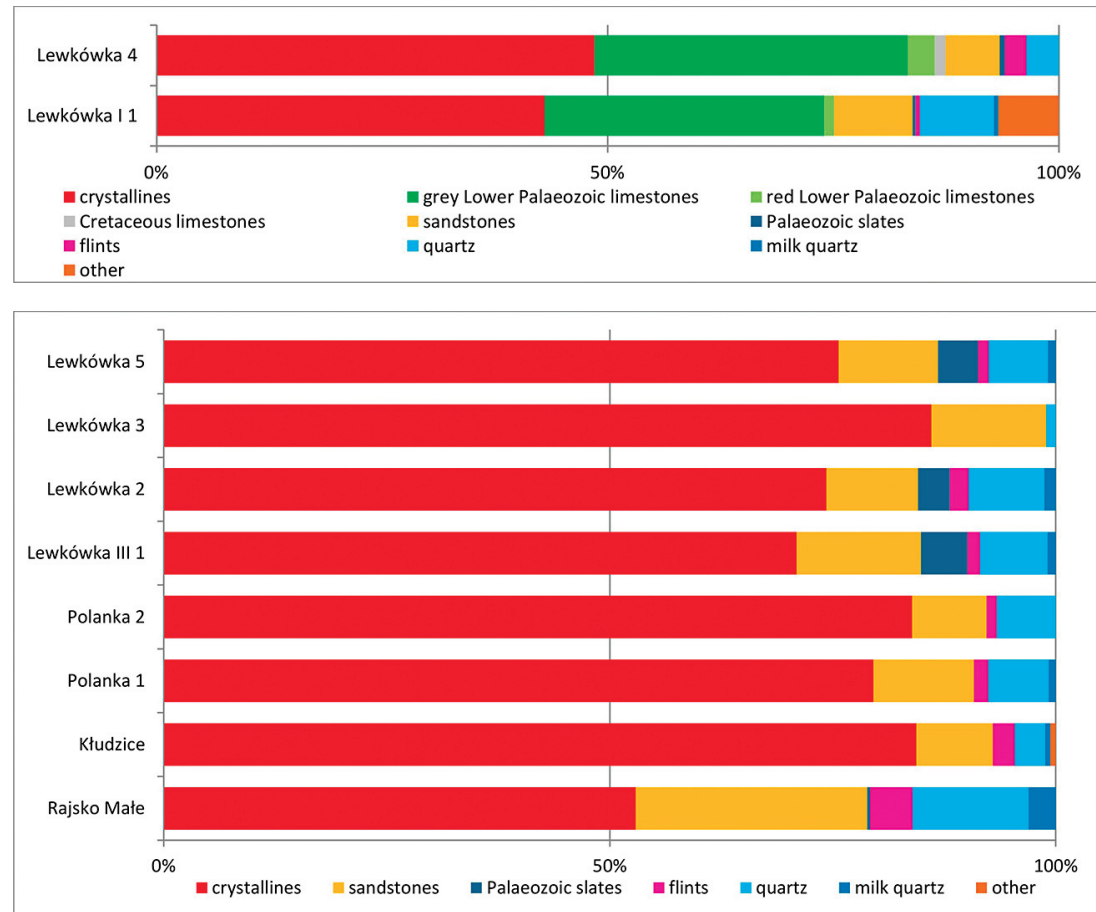

Fig. 10. Percentages of the various petrographical groups of the Warthian fluvioglacial fresh gravel (4-10 $\mathrm{mm}$ fraction) in zone IV (Piotrków Plain) (for legend see Table 2)

Fig. 11. Percentages of the various petrographical groups of the Warthian fluvioglacial weathered gravel (4-10 $\mathrm{mm}$ fraction) in zone IV (Piotrków Plain) (for legend see Table 2) the presence of fragile Palaeozoic slates five out of the six samples (Ps 0.4-5.2\%; Fig. 10, 11).

Crystalline rocks dominate the gravels collected from weathered deposits (Cr 76.0\%; Table 4). Such a large percentage was not found in any of the other zones. On the other hand, sandstones have the lowest percentage of all zones, with merely $12.8 \%$. Crystalline rocks being so numerous, a high percentage of flint - which is equally resistant to damage - is to be expected. Flint, however, constitutes only $1.8 \%$ of the gravel from weathered deposits in this zone, which is the lowest percentage from all zones. Also quartz is not well represented, reaching only $6.7 \%$, the lowest percentage of all zones.

\section{Results of the petrographical analysis of the 20-60 $\mathrm{mm}$ fraction}

A petrographical analysis of the coarse-grained gravel (20-60 mm) was carried out for seven samples from zones I, II and III (Table 1, Fig. 12). Five samples were collected from fresh sediments, two from weathered deposits.

\subsection{Zone I: Radomsko Hills and Przedbórz Upland}

The gravels from zone I have similar compositions and percentages of petrographical types (Figs

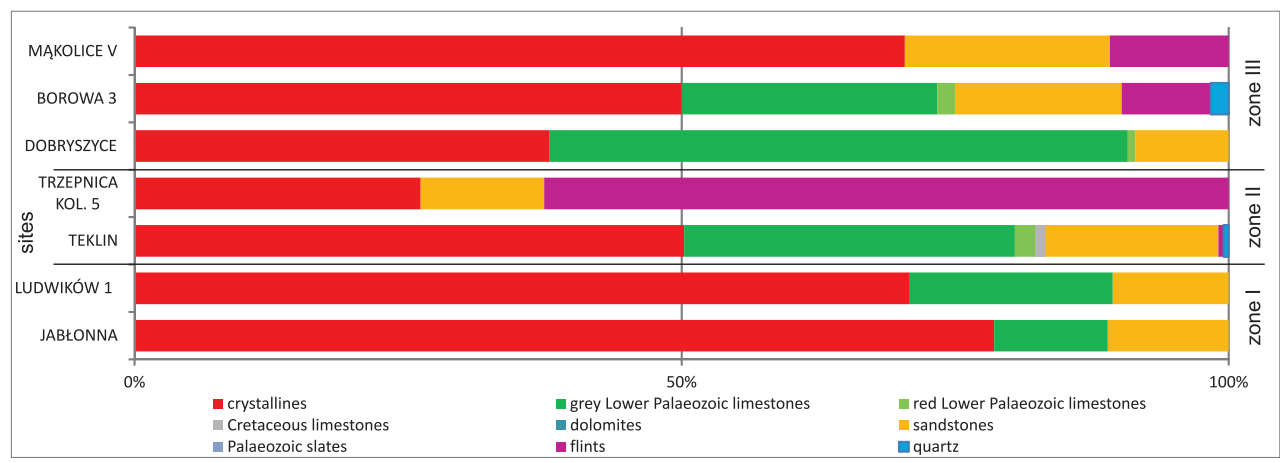

Fig. 12. Percentages of the various petrographical groups of the Warthian fluvioglacial gravel (20-60 mm fraction) 
12, 13). More than $70 \%$ of each sample consists of crystalline rocks, and the percentage of the Lower Palaeozoic limestones falls within the range of approx. $10-18 \%$; sandstones are less numerous, but have in both samples almost the same value (approx. $11 \%$ ).

The group of indicator erratics, which constitutes up to $17.5 \%$ is dominated by rocks from Småland (Fig. 13): Småland granites and grey and red Växjö granites. Åland quartz porphyries come from outcrops on the Alland Islands. Some rocks originated in Dalarna. In the sample from Jabłonna, two specimens of Stockholm granite from Uppland occur. The theoretical centres of the source areas for both samples are located close to each other (Figs 13 and 16 ): TSC J: $58.4^{\circ} \mathrm{N}, 17^{\circ} \mathrm{E}$; and TSC L: $58.7^{\circ} \mathrm{N}$, $16.8^{\circ} \mathrm{E}$.

\subsection{Zone II: Dobryszyce Hills}

The petrographical composition of the coarsegrained gravel of this zone varies (Fig. 12). The sample from Teklin represents a typical composition and percentage of petrographical types, but the sample from nearby Trzepnica Kolonia lacks carbonate rocks. As carbonate rocks are not present in the medium-grained gravel of this site either, from the gravel of the samples probably was derived from a decalcified zone, presumably the Palaeogene substratum, which is built of rock debris and weathered clays. The highest percentage in the sample from this site is taken by flint (approx. 63\%). Further, slightly over $26 \%$ of crystalline rocks and approx. $11 \%$ of sandstones are present. The sample from Teklin consists for half of crystalline rocks, whereas Lower Palaeozoic limestones amount to $30 \%$, and sandstones to $16 \%$. Trace amounts occur of red Ordovician limestones and Cretaceous limestones - fragile and only rarely present - as well as flint and quartz.

The two sites of zone II thus differ in the quantity of flint $(\mathrm{F})$. Taking into account that flint occurs in the 4-10 mm fraction in an above-average quantity, it must be assumed that the deposits in Trzepnica Kolonia were enriched in this rock type by erosion of local outcrops of a deeper bed. The afore-mentioned weathered Palaeogene substratum, lacking carbonate rocks, may have been enriched in flint.

In both samples erratics from outcrops in south-eastern Sweden are present; they concern crystalline Småland and Växjö granites and also Västervik quartzites and Tessini and Kalmarsund sandstones (Fig. 14). Erratics from the Alland Is- lands are also present as well as a few specimens of erratics from Dalarna in central Sweden. Also crystalline and sedimentary erratics from Skåne and Bornholm, so from the southern Scandinavian outcrops, are present.

The theoretical centres of the source areas of the erratics are all positioned at the same longitude, i.e. $16.6^{\circ} \mathrm{E}$ (Figs 14, 16). The difference in the latitude of both TSC amounts only to $0.6^{\circ}: \mathrm{T}$ is positioned at $57.6^{\circ} \mathrm{N}, \mathrm{TK}$ at $58.2^{\circ} \mathrm{N}$ (Fig. 14). The indicator erratics constitute $12 \%(\mathrm{TK})$ and $22 \%(\mathrm{~T})$, respectively.

The deposit from which the sample from Trzepnica Kolonia was taken was enriched in local flint stones. The lack of limestones may indicate that the sample was collected from a weathered level.

\subsection{Zone III: Bełchatów Plateau, Widawka River lobe of the Warthian ice sheet}

The petrographical analysis shows that the three samples differ from one another by the presence of the Lower Palaeozoic limestones and flint (Figs $12,15)$. The sample from Dobryszyce is dominated (more than $50 \%$ ) by grey Silurian and red Ordovician limestones. Around 38\% consists of crystalline rocks and the rest (8.5\%) are sandstones. At Borowa also other petrographical groups are present. Apart from the crystalline rocks (50\%), the Lower Palaeozoic limestones (25\%, including red Ordovician) and sandstones (15\%), flint and quartz are present. In contrast, the sample from Mąkolice contains only three petrographical types: crystalline rocks (over 70\%), sandstones (approx. 19\%) and flints (approx. $11 \%$ ). The results indicate a tendency from south to north: the percentage of the Lower Palaeozoic limestones decreases while the crystalline rocks and flint increase.

Rocks from south-eastern Sweden are the most common (Fig. 15). It is the source area of crystalline rocks like Småland and Växjö granites as well as of Västervik quartzites and Tessini sandstones. Erratics from the Åland Islands are present in each sample; they are mainly granites, including Åland rapakivi. At Dobryszyce and Borowa, where the Lower Palaeozoic limestones occur, single specimens from Bornholm are present; at Dobryszyce and Mąkolice specimens from Dalarna occur.

The geographical co-ordinates of the theoretical centres of the source areas of the erratics differ; they are for TSC D $58^{\circ} \mathrm{N}$, and $16.9^{\circ} \mathrm{E}$; for TSC B $57.5^{\circ} \mathrm{N}$, $16.4^{\circ} \mathrm{E}$; and for $\mathrm{TSC} \mathrm{M} 58.2^{\circ} \mathrm{N}, 16.6^{\circ} \mathrm{E}$ (Figs 15 and 16). The percentage of indicator erratics in the samples fluctuates between $13 \%$ and $17 \%$. 

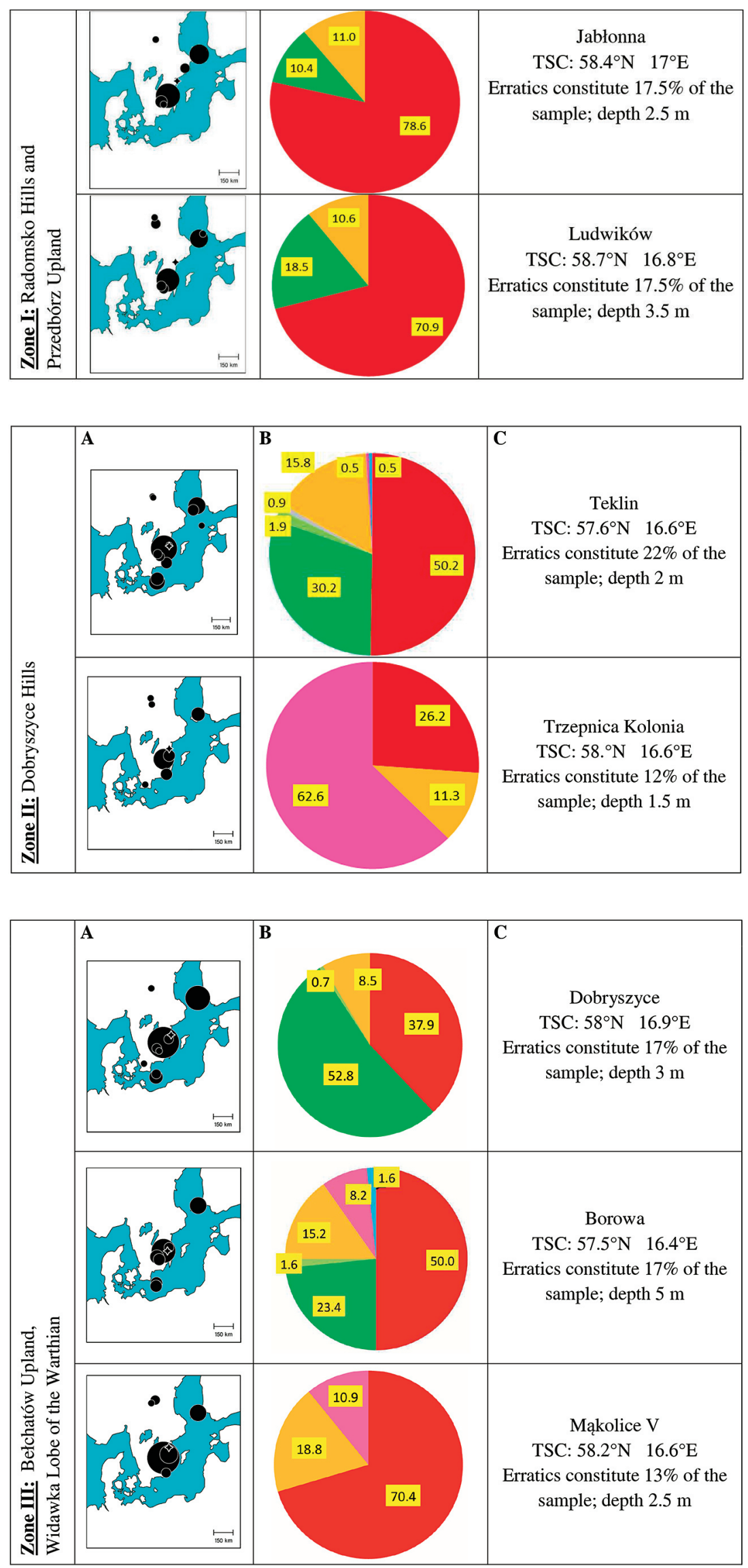

Fig. 13. Extended petrographical analysis of the coarse gravel (20$60 \mathrm{~mm}$ fraction) from zone I.

A: Source areas of the indicator erratics with locations of the TSC (theoretical stone centre); B: Percentages of the various petrographical types of the coarse (20-60 mm) gravel; C: Additional information.

Fig. 14. Extended petrographical analysis of the coarse gravel (20$60 \mathrm{~mm}$ fraction) from zone II

A: Source areas of the indicator erratics with locations of the TSC (theoretical stone centre); B: Percentages of the various petrographical types of the coarse (20-60 mm) gravel; C: Additional information

Fig. 15. Extended petrographical analysis of the coarse $(20-60 \mathrm{~mm})$ gravel from zone III

A: Source areas of the indicator erratics with locations of the TSC (theoretical stone centre); B: Percentages of the various petrographical types of the coarse (20-60 mm) gravel; C: Additional information. 


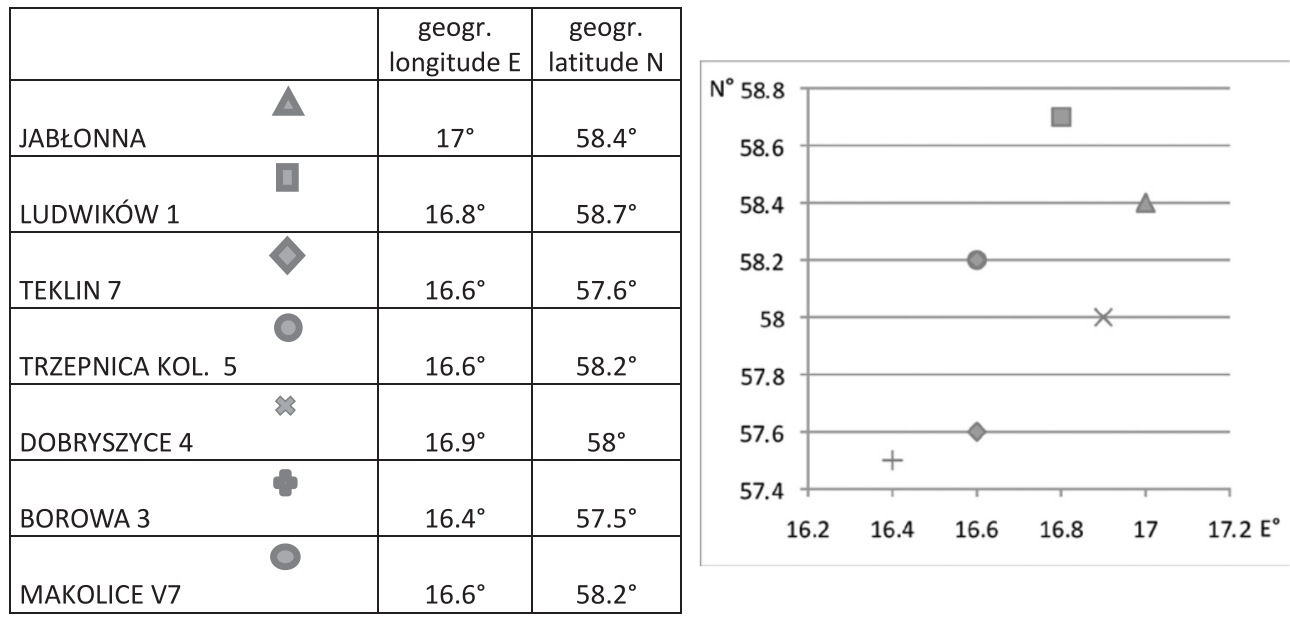

Fig. 16. Geographical co-ordinates and location of the theoretical erratic centres (TSC) of the samples of the coarse (20-60 mm) gravel from the study area

\section{Discussion}

\subsection{Causes the changes in petrography of the fluvioglacial deposits}

\subsubsection{The $4-10 \mathrm{~mm}$ fraction}

The petrographical composition of fluvioglacial gravel of 4-10 mm deposited changed during the decline of the ice sheet decline in central Poland. The main petrographical types are crystalline rocks and, for fresh (unweathered) deposits, Lower Palaeozoic limestones. These two rock types show, for samples from fresh deposits, an opposite trend: the percentage of crystalline rocks increases from south to north, whereas that of the Lower Palaeozoic limestones (which are highly susceptible to weathering, are the most frequent in the southern parts of the study area, decreasing systematically northwards. The deposits in the southern part of the study area, which had been subjected to diagenetic processes longer than the northern ones (because they were the earliest to be set free from the ice sheet), might be expected to contain the most resistant components, but the opposite is found. Hence, the hypothesis repeatedly brought up in literature about the influence of weathering on the petrographical composition (e.g. Lisicki, 1998c; Woźniak, 2004) must be considered erroneous for the sediments under study here, particularly because the non-resistant clasts become more frequent with increasing time of being outside the ice sheet. A similar trend is shown by the average percentage of quartz (Table 3 ). Theoretically, the quartz frequency should increase from north to south because the more southern deposits were deposited by the ice sheet earlier than the deposits representing later phases of deglaciation (i.e. fluvioglacial gravels in the northern region). Our study shows, however, that the frequency of quartz decreases from the north to the south.

The average percentage of sandstones in the samples from fresh gravel is stable (Table 3), whereas it is highly variable in the samples from weathered sediments (Table 4). For example, a sample from Kamieńsk in zone III is characterised by a sandstone percentage of $48.1 \%$, which is higher than the average (Fig. 9). In our opinion, these gravels were derived from older glacigenic sediments and were deposited again in Warthian sediments.

The less frequent rocks (up to 5\%) also deserve attention, particularly the flints and the Palaeozoic slates (Tables 3, 4). The presence of flint is a characteristic feature of tills and fluvioglacial deposits (Haldorsen, 1982; Böse, 1989). Flint occurs in all four zones, but most frequently $(5.8 \%)$ in the decalcified gravels of zone II (Dobryszyce Hills; Table 4). In other zones, the average flint percentage does not exceed $3.4 \%$. Soft and fragile Palaeozoic slates are characteristic for all four studied zones, but only in unweathered deposits. Their average percentage varies (Table 3), but most often fluctuates around $0.5 \%$. The highest percentage of Palaeozoic slates occurs in zone II (Dobryszyce Hills); their frequency there is three times higher than in the other zones (Table 3). Their presence in central Poland cannot be explained by glacial transport from Scandinavia as non-resistant rocks should have been destroyed during the long englacial transport. The Palaeozoic slates undergo complete destruction even during the relatively short (from a few to something like a dozen kilometres) glacial transport (e.g. Lilliesköld, 1990). The erosion of these rocks was more intense in a fluvioglacial environment. Thus, the 
presence of the slates must be connected with other factors, such as a local outcrop of ice-rafted rocks in the near vicinity of the research area, especially in zone IV (Piotrków Plain). A possible glacial transport from the NNE or NE within an ice stream along the pre-Luciąża valley can, however, is not neglected.

\subsubsection{The $20-60 \mathrm{~mm}$ fraction}

The coarse-grained $(20-60 \mathrm{~mm})$ gravels contain less limestones and more crystalline rocks than the medium-grained (4-10 mm) gravels. This trend seems characteristic for fluvioglacial deposits (Górska, 2000).

Sandstones are the third petrographical group in the coarse fraction. Their frequency is relatively constant (10-15\%). Palaeozoic slates are absent, but flint is present in four samples of this fraction. Their frequent presence at the Trzepnica Kolonia site might be connected with the existence of a nearby local outcrop.

Quartz is distinctly less frequent than in the medium-grained gravel, which is characteristic of this petrographical group (e.g. Schulz, 1996, 1999). It is connected with the crystallographic structure of quartz and the geological setting of Scandinavian outcrops (e.g. a vein-rich rock).

\subsection{Directions of the Warthian ice-sheet advance}

The analysis of the indicator and statistical erratics suggests that the main stream of the Warthian ice sheet, which deposited glaciofluvial sediments in the southern part of the study area, started from the vicinity of Åland Islands and advanced through the western part of the Baltic Basin. The Warthian ice-sheet transgression along the eastern coast of southern Sweden is supported by the high percentage of crystalline rocks and the low amount of carbonate rocks in the samples from zone I (Radomsko Hills and Przedbórz Upland). The limestones and sandstones in this zone may have been transported incorporated in the ice sheet after having been eroded from the basement of the western part of the central Baltic, in the vicinities of Öland and the Gotland islands. Most probably the office mass bypassed Skåne (Scania), Blekinge and Bornholm: rocks from these areas are lacking.

The deposits of the Dobryszyce Hills (zone II) were transported by the same glacial stream, which can be deduced from the indicator erratics from around Teklin, representing mainly rocks derived from south-eastern Sweden: crystalline Småland and Växjö granites along with Tessini and Kalmarsund sandstones. Crystalline and sedimentary indicator erratics from Skåne and Bornholm are also present. Some statistical erratics (Jotnian Baltic sandstones, Silurian and Ordovician limestones) were found. It indicates that the ice sheet advanced through the Baltic trough and the eastern parts of southern Sweden.

The Warthian ice sheet that left sediments in zone III (Bełchatów Plateau, Widawka River basin) must have moved through the Baltic area with Ordovician and Silurian limestones and the area of crystalline rocks of SE Sweden, the Åland Islands and Bornholm. The high percentage of crystalline rocks suggests that the ice sheet travelled along Svekofenids and the Trans-Scandinavian Igneous Belt (cf. Górska-Zabielska, 2008).

The petrographical differences between the two size fractions support the hypothesis that two glacial lobes came together in the study area: the lobe of the Widawka and Rawka rivers and the lobe of the Pilica and Luciąża rivers. The petrographical analyses point out that the ice masses advanced from the NE to NNW (the Widawka lobe) and from the NE to ENE (the Rawka, Pilica and Luciąża lobe).

\section{Conclusions}

Petrographical investigations were conducted with respect to: (1) fraction (medium- and coarsegrained gravels, i.e. $4-10 \mathrm{~mm}$ and $20-60 \mathrm{~mm}$, respectively), (2) state of the deposits (fresh: 32 samples; weathered: 30 samples), and (3) zones (I: Radomsko Hills and Przedbórz Upland; II: Dobryszyce Hills; III: Bełchatów Plateau - Widawka Lobe; IV: Piotrków Plain).

The two main petrographical groups in the medium-grained gravels consist of Lower Palaeozoic limestones and crystalline rocks. From the south to the north of the study area, the medium-grained gravels show systematically decreasing amounts of Lower Palaeozoic limestones and increasing amounts of crystalline rocks and flint. No such tendency was found for the coarse-grained gravel, most probably because of an insufficient number of samples.

The percentage of sandstones is more or less constant in all samples, in both the fresh and the weathered deposits.

A remarkable feature is a large amount of quartz clasts in the medium-gravel fraction of unweathered deposits (Table 3). Their amount increases from zone I to zone IV, i.e. from south to north. In 
weathered gravel, their amount in zone II is twice as high as in the neighbouring zones (Table 4).

Also in the 4-10 mm fraction, fragile Palaeozoic slates make up approx. $0.2 \%$, apart from in samples from fresh sediment in zone II (Table 3), where their amount is three times higher. Flint is more frequent in samples from weathered deposits of zone II. The source areas of the flint and Palaeozoic slates are presumably small outcrops not far away from the final depositional site.

The indicator and statistical erratics indicate that the main stream of the Warthian ice sheet, which left deposits in the southern part of the study area, started in the vicinity of the Alland Islands, the travelled across the western part of the Baltic Basin and along the eastern coast of southern Sweden.

The clasts in the deposits of the Dobryszyce Hills (zone II) were transported by the same glacial stream, as evidenced both by the indicator erratics format the Teklin site: mainly rocks derived from the Baltic Basin (red Baltic porphyry, Bornholm granites, Tessini sandstones), and by the statistical erratics (Jotnian Baltic sandstones, Silurian and Ordovician limestones).

The ice sheet which left deposits in zone III advanced through the Baltic area with Palaeozoic limestones and through the area with crystalline rocks in SE Sweden. In the region of Borowa and Mąkolice, the glacial stream advanced across a local area with flint. The indicator and statistical erratics thus suggest that the source areas of the Warthian ice sheet were magmatic and sedimentary areas in both the Baltic and south-eastern Sweden. The theoretical centre of the area from where the coarsegrained gravel have come, is a narrow area situated between $16.4^{\circ} \mathrm{E}$ and $17.0^{\circ} \mathrm{E}$ and between $57.5^{\circ} \mathrm{N}$ and $58.7^{\circ} \mathrm{N}$.

The petrographical characteristics of the fluvioglacial gravel supports the hypothesis that the study area is a zone where two glacial lobes joined: the lobe of the Widawka and the lobe of the Rawka, Pilica and Luciąża rivers. The present study proves that the Warthian ice masses advanced from the NNW (the Widawka lobe) and from the NE to ENE (the Rawka, Pilica and Luciąża lobe).

\section{Acknowledgements}

The present contribution is an outcome of the National Science Centre project 'Morphogenesis of the area between Radomsko, Przedbórz and Piotrków Trybunalski as evidence of the determinants, course and role of the youngest glacial events of the borderland of central Poland's Lowlands and Uplands' (N N306 721140; 2011-2013). We thank everybody who helped us collecting samples of erratics in the field. Our sincere thanks go to Małgorzata Gościńska-Kolanko for preparing some figures. We also appreciate the input of two anonymous reviewers for improving an earlier version of this contribution.

\section{References}

Böse, M., 1979. Die geomorphologische Entwicklung im westlichen Berlin nach neueren stratigraphischen Untersuchungen. Berliner Geographische Abhandlungen 28, $43 \mathrm{pp}$.

Böse, M., 1983. Zum Aufbau der Sedimente im Berliner Urstromtal nach Kiesanalysen von Geschiebemergeln. Zeitschrift für Geomorphologie NF 27, 139-145.

Böse, M., 1989. Methodisch-stratigraphische Studien und paläomorphologische Untersuchungen zum Pleistozän südlich der Ostsee. Berliner Geographische Abhandlungen 51, $114 \mathrm{pp}$.

Böse, M., 1995. Petrographical composition of the tills and glaciotectonic structures in the clay pit at Włoszakowice. Quaestiones Geographicae SI 4, 73-78.

Böse, M. \& Górska, M., 1995. Lithostratigraphical studies in the outcrop at Ujście, Torun-Eberswalde Pradolina, western Poland. Eiszeitalter und Gegenwart 45, 1-14.

Cepek, A.G., 1962. Zur Grundmoränenstratigraphie in Brandenburg. Berichte der Deutschen Gesellschaft für Geologische Wissenschaften 7, 275-278.

Cepek, A.G., 1969. Zur Bestimmung und stratigraphischen Bedeutung der Dolomitgeschiebe in den Grundmoränen im Nordteil der DDR. Geologie 18, 657-673.

Cepek, A.G., 1973. Zur stratigraphischen Interpretation des Quartärs der Stoltera bei Warnemünde nach neuen Geschiebeanalysen. Zeitschrift für Geologische Wissenschaften 1, 1155-1171.

Cepek, A.G., 1975. Zur Stratigraphie des Quartärs in den Kliffprofilen nördlich Saßnitz/Rügen. Wissenschaftliche Zeitschrift der Ernst-Moritz-Arndt-Universität Greifswald 24, 171-174.

Cepek, A.G., 1981. Drei Interglaziale in einer mittel- bis jungpleistozänen Schichtenfolge östlich von Berlin. Zeitschrift für Angewandte Geologie 27, 397-405.

Czerwonka, J.A. \& Krzyszkowski, D., 1994. Pleistocene stratigraphy and till petrography of the central Great Poland Lowland. Folia Quaternaria 65, 7-71.

Czubla, P. \& Wachecka-Kotkowska, L., 2009. Pozycja stratygraficzna glin lodowcowych w Masłowicach (Wyżyna Przedborska) w świetle badań petrograficznych [Stratigraphic position of till in Masłowice (Przedbórz Upland) in light of the petrographical studies]. [In:] M. Żarski \& S. Lisicki (Eds): Strefa marginalna zlodowacenia warty i pojezierza plejstoceńskie na potudniowym Podlasiu [The marginal zone of the Warthian and Pleistocene lakelands in S Podlasie]. Polish Geological Institute - National Research Institute, Warszawa, 56-57.

Górska, M., 1999. Advantages and disadvantages of petrographical analyses of glacial sediments. Kwartalnik Geologiczny 43, 241-250. 
Górska, M., 2000a. Wybrane właściwości petrograficzne vistuliańskich moren dennych środkowej i zachodniej Wielkopolski oraz ich znaczenia dla oceny dynamiki ostatniego lądolodu [Some petrographical features of Vistulian lodgement till in the central and southern Wielkopolska Lowlands and their significance for estimating the dynamics of the last ice sheet]. Prace Poznańskiego Towarzystwa Przyjaciót Nauk 26, 145 pp.

Górska, M., 2002a. Petrographie von uckermärkischen Geschieben. Geologische Brandenburgische Beiträge 3, 35-47.

Górska, M., 2002b. Petrografia osadów akumulacji lodowcowej i wodnolodowcowej Pojezierza Drawskiego [Petrography of glacial and fluvioglacial sediments of the Drawno Lakeland]. Badania Fizjograficzne nad Polską Zachodnia 53, 29-42.

Górska, M., 2006. Narzutniaki przewodnie z Sobolewa (sandr suwalsko-augustowski) [Indicator erratics from Sobolewo (Suwałki-Augustów) outwash plain]. Prace Komisji Paleogeografii Czwartorzędu PAU III, 209212.

Górska-Zabielska, M., 2008. Fennoskandzkie obszary alimentacyjne osadów akumulacji glacjalnej i glacjofluwialnej lobu Odry [Fennoscandian source areas of glacial and glaciofluvial deposits of the Odra lobe (north-western Poland and north-eastern Germany)]. Adam Mickiewicz University Press, Poznań 78, 330 pp.

Górska-Zabielska, M. \& Zabielski, R., 2010. Petrographic analysis and indicator erratics of gravels of the Odra Lobe. Studia Quaternaria 27, 17-25.

Górska-Zabielska, M. \& Zabielski R., 2011. Kleinkieszählung und Leitgeschiebe des Oder Lobus. Zeitschrift für Geomorphologie 55, 493-513.

Haldorsen, S., 1982. The enrichment of quartz in tills. [In:] E.B. Evenson, Ch. Schlüchter \& J. Rabassa (Eds): Till and related deposits - Proceedings of the INQUA-Symposia on the Genesis and Lithology of Quaternary Deposits (USA 1981, Argentina 1982), 141-150.

Hesemann, J., 1975. Kristalline Geschiebe der nordischen Vereisungen. Geologisches Landesamt Nordrhein-Westphalen, Krefeld, 267 pp.

Kasprzak, L., 1985. A model of push moraine development in the marginal zone of the Leszno Phase, west central Poland. Quaternary Studies in Poland 6, 23-54.

Kasprzak, L., 1992. The Leszno-Osieczna push moraine ridges: a case study of Vistulian maximum ice-marginal features. [In:] M. Böse, L. Kasprzak, S. Kozarski (Eds): Last Ice Sheet Dynamics and Deglaciation in the North European Plain. The Peribaltic Group, IGCP 253, Poznań-Berlin, 22-27.

Kasprzak, L., 1997. Main lithofacial complexes of the Sława Śląska ice lobe (Vistulian glaciation, Great Poland Lowland). Quaternary Studies in Poland 14, 17-39.

Kasprzak, L. \& Kozarski, S., 1984. Analiza facjalna osadów strefy marginalnej fazy poznańskiej ostatniego zlodowacenia w środkowej Wielkopolsce [Facies analysis of sediments from the marginal zone of the Poznan phase, last glaciation, in central Great Poland]. Wydawnictwo Naukowe Uniwersytetu im. A. Mickiewicza, Geografia 29, 54 pp.
Korn, J., 1927. Die wichtigste Leitgeschiebe der nordischen kristallinen Gesteine im norddeutschen Flachlande. Preussische Geologische Landesanstalt, Berlin, 64 pp.

Kozarski, S., 1988. Time and dynamics of the last Scandinavian ice-sheet retreat from northwestern Poland. Geographia Polonica 55, 91-101.

Krienke, K., 2003. Südostrügen im Weichsel-Hochglazial - lithostratigraphische, lithofazielle, strukturgeologische und landschaftsgenetische Studien zur jüngsten Vergletscherung im Küstenraum Vorpommerns (NE Deutschland). Greifswalder Geowissenschaftlliche Beiträge 12, 147 pp.

Lilliesköld, M., 1990. Lithology and transport distance of glaciofluvial material. [In:] R. Kujansuu \& M. Saarnisto (Eds): Glacial indicator tracing. Balkema, Rotterdam, 151-164.

Lipka, E., 2011. Zróżnicowanie cech petrograficznych osadów polodowcowych na Wysoczyźnie Lubuskiej [Petrographical variety of postglacial sediments in the Lubuska Upland]. Archiwum Wydziału Nauk Geograficznych i Geologicznych Uniwersytetu im. A. Mickiewicza, $108 \mathrm{pp}$.

Lisicki, S., 1998a. Attempt of lithostratigraphic correlation of tills in north-eastern Poland and southern Lithuania. Geological Quarterly 42, 161-172.

Lisicki, S., 1998b. Interpretacja wyników analizy petrograficznej frakcji żwirowej glin zwałowych w nawiązaniu do ich genezy [Interpretation of the results of the petrographic analysis of till-derived gravels according to their genesis]. Przeglad Geologiczny 46, 410-416.

Lüttig, G., 1958. Methodische Fragen der Geschiebeforschung. Geologisches Jahrbuch 75, 361-418.

Lüttig, G., 1995. Geschiebezählungen - eine terminologische Richtigstellung. Geschiebekunde Aktuell 11, 109-112.

Lüttig, G., 1999. Geschiebestatistische Anmerkungen zur Quartärstratigraphie des nordischen Vereisungsgebietes. Eiszeitalter und Gegenwart 49, 144-163.

Meyer, K.-D., 1983. Indicator pebble and stone count methods. [In:] Ehlers (Ed.), Glacial deposits in NorthWest Europe. Balkema, Rotterdam, 275-287.

Meyer, K.-D. 1985. Zur Methodik und über den Wert von Geschiebezählungen. Der Geschiebesammler 19, 75-83.

Meyer, K.-D., 1994. Exkursionsführer zur Quartärgeologie des nordöstlichen Niedersachsen. Geschiebekunde Aktuell, Sonderheft 4, $36 \mathrm{pp}$.

Meyer, K.-D., 1998. Geschiebekundlich-stratigraphische Untersuchungen in der südlichen Lüneburger Heide. Mitteilungen aus dem Geologischen Institut der Universität Hannover 38, 178-188.

Meyer, K.-D., 2000. Geschiebekundlich-stratigraphische Untersuchungen im Hannoverschen Wendland (Niedersachsen). Brandenburgische Geowissenschaftliche Beiträge 7, 115-125.

Pettersson, G., 1995. Latest ice movement from the east along Noteć river. [In:] L. Kasprzak, A. Kostrzewski \& B. Nowaczyk (Eds): Późnoczwartorzędowy rozwój rzeźby i zmiany środowiska przyrodniczego [Late-Quaternary development of the relief and changes of the natural 
environment]. Adam Mickiewicz University Press, Poznań, $59 \mathrm{p}$.

Pettersson, G., 1997. Unexpected ice movement directions during the last deglaciation in Ujście, NW Poland stratigraphical investigations. Quaternary Studies in Poland 14, 85-94.

Pettersson, G., 2002. Weichselian glaciations in the middle Notec River region, northwest Poland. LUNDQUA THESIS, 47. Quaternary Geology, Dept. of Geology, Lund University, PhD Dissertation, 23 pp.

Rudolph, F., 2005. Strandsteine. Sammeln E Bestimmen von Steinen an der Ostseeküste. Wachholtz Verlag, Neumünster, $160 \mathrm{pp}$.

Rühberg, N., 1999. Über den Wert der Kleingeschiebezählungen (KGZ). Geschiebekunde Aktuell 15, 3, 87-100.

Rühberg, N. \& Krienke, H.-D., 1977. Zur Geschiebeführung der Weichselgrundmoräne im westlichen Odermündungsgebiet. Zeitschrift für die Geologische Wissenschaft 5, 805-813.

Rutkowski, J., 1995a. Badania petrograficzne żwirów [Petrographic investigation of gravels]. [In:] E. Mycielska-Dowgiałło \& J. Rutkowski (Eds): Badania osadów czwartorzędowych. Wybrane metody i interpretacja wyników [Investigation of the Quaternary sediments. Selected methods and interpretation of the results]. Warsaw University, Warszawa, 133-150.

Rutkowski, J., 1995b. Badania uziarnienia osadów bardzo gruboziarnistych [Investigation of the grain-size composition of very coarse-grained sediments]. [In:] E. Mycielska-Dowgiałło \& J. Rutkowski (Eds): Badania osadów czwartorzędowych. Wybrane metody i interpretacja wyników [Investigation of Quaternary sediments. Selected methods and interpretation of the results]. Warsaw University, Warszawa, 106-114.

Saarnisto, M., 1990. An outline of glacial indicator tracing. [In:] R. Kujansuu \& M. Saarnisto (Eds): Glacial indicator tracing. Balkema, Rotterdam, 1-13.

Schulz, W., 1973. Rhombenporphyr-Geschiebe und deren östliche Verbreitungsgrenze im nordeuropäischen Vereisungsgebiet. Zeitschrift für die Geologische Wissenschaft 9, 1141-1154.

Schulz, W., 2003. Geologischer Führer für den norddeutschen Geschiebesammler. CW Verlagsgruppe, Schwerin, 508 pp.

Smed, P., 1993. Indicator studies: a critical review and a new data-presentation method. Bulletin of the Geological Society of Denmark 40, 332-340.
Smed, P. \& Ehlers, J., 2002. Steine aus dem Norden. Geschiebe als Zeugen der Eiszeit in Norddeutschland. Gebrüder Borntraeger, Berlin, Stuttgart, 194 pp.

Stanisz, A., 2001. Przystęny kurs statystyki w oparciu o program STATISTICA PL na przykładach z medycyny [A statistics course based on the STATISTICA PL program with examples from medicine]. StatSoft, Kraków, 362 pp.

Svenson, Ch., 2005. Geschützte Findlinge der Insel Rügen. Landesamt für Umwelt, Naturschutz und Geologie Mecklenburg-Vorpommern, Güstrow, 28 pp.

Trembaczowski, J., 1961. Przyczynki do metodyki badań granulometryczno-petrograficznych utworów morenowych [Contributions to the methods for investigation of the grain-size and petrography of morainic deposits]. Annales Universitatis Mariae Curie-Skłodowska (Lublin) B 16, 63-95.

Turkowska, K., 2006. Geomorfologia regionu tódzkiego [Geomorphology of the Łódź region]. Łódź University Press, Łódź, 237 pp.

Vinx, R., 1993. Hochauflösende Rekonstruktion von Eistransportwegen: die "Leitserienmethode". Archiv für Geschiebekunde 1, 625-640.

Wachecka-Kotkowska, L., Czubla, P. \& Górska-Zabielska, M., 2012. Petrografia kompleksu środkowopolskiego w okolicach Piotrkowa Trybunalskiego [Petrography of the Middle Polish Complex in the vicinity of Piotrków Trybunalski]. [In:] Korelacja osadów plejstocenu na pograniczu polsko-niemieckim $w$ dolinie dolnej Odry [Correlation of Pleistocene deposits in the Polish-German border area, lower Odra valley]. PIG-PIB, Warszawa, 110-113.

Wachecka-Kotkowska, L., Czubla, P., Górska-Zabielska, M., Król, E. \& Barczuk, A., 2013. Saalian palaeogeography of central Poland - Mąkolice case. International Symposium "Palaeolandscapes from Saalian to Weichselian", South Eastern Lithuania. Abstracts, 101102.

Zabielski, R., 1996. Application of a petrographic method of the till floes. Geological Quarterly 40, 283-298.

Zandstra, J.G., 1999. Platenatlas van noordelijke kristallijne gidsgesteenten [Illustrated atlas of crystalline indicator erratics]. Backhuys Publishers, Leiden, 412 pp.

Manuscript received: 21 January 2014 Revision accepted: 6 August 2014 